Original Research

\title{
Correlation Knowledge to Hypothermic Handling Practices in Students
}

\section{Dewi Sinta Windya Kustina ${ }^{1}$}

1 Master of Nursing Program, Universitas Muhammadiyah Semarang, Indonesia

\section{Article Info}

\section{Article History:}

Submit March 5th, 2021

Accepted March 25st, 2021

Published March 28th 2021

\section{Keywords:}

Hypothermia; Knowledge;

Practices

\begin{abstract}
Hypothermia is a decrease in core body temperature to $<35^{\circ} \mathrm{C}$ due to heat loss. Factors causing hypothermia are cold weather, exposure to cold winds at high altitudes, immersion in cold water, and prolonged exposure to cold. Hypothermia is more common in hikers or mapala because they do activities exploring the highlands. The purpose of this study was to determine the relationship between knowledge of hypothermia and the practice of handling hypothermia in Mapala. This study used a correlation study method with a cross-sectional approach. The population in this study were Mapala UNISSULA, UNNES, and USM with a total of 52 students. The sampling technique was purposive sampling, the number of samples of this study was 30 students. The results of the Spearman Rank statistical test obtained a value of $\rho$ value of $0.738(\rho \geq 0.05)$, so it was stated that there was no relationship between knowledge of hypothermia and the practice of handling hypothermia in Nature Lovers Students. Recommendations from research so that mapala members increase their knowledge and practice in handling emergency hypothermia by conducting ongoing training.
\end{abstract}

\section{INTRODUCTION}

Cold is a low-temperature environment compared to the human core body temperature which is $15^{\circ} \mathrm{C}$, the human core body temperature is around $37^{\circ} \mathrm{C}$. Cold can cause injury when the body is unable to maintain core temperature. ${ }^{1-3}$ Cold injuries that can occur are hypothermia, frostbite, chilblains, trench foot and allergic reactions to cold. ${ }^{1,2}$ Hypothermia causes deaths of up to 700 people per year in the US during the 20 years from 1979-1998, half of them due to cold weather. ${ }^{3,4}$ In Canada, 411 people died from hypothermia, frostbite, and other cold injuries during 1992-1996. ${ }^{5}$
Hypothermia is a condition where the body temperature drops abnormally low below $35^{\circ} \mathrm{C}$ due to heat loss. Loss of body heat occurs in four ways: conduction, radiation, convection and evaporation. The severity of hypothermia was defined based on core temperature, namely: mild hypothermia $\left(32^{\circ}-35^{\circ} \mathrm{C}\right)$, moderate hypothermia $\left(28^{\circ}\right.$ $32^{\circ} \mathrm{C}$ ) and severe hypothermia (below $28^{\circ} \mathrm{C}$ )..$^{3,6}$ Factors causing hypothermia are cold weather, exposure to cold winds at high altitudes, immersion in cold water, and prolonged exposure to cold. Factors that can aggravate hypothermia include wet clothes, fatigue, dehydration, poor food intake, alcohol intake and drugs. ${ }^{1,2,7}$

Corresponding author: 
Complications that can occur from hypothermia are disturbances in the response to thermoregulation, cellular dysfunction, ischemia, oedema. Hypothermia can reduce cardiac contractility due to tissue depletion, blood pressure will decrease until shock occurs. Hypothermia can reduce consciousness to become apathetic, loss of reflex swallowing and aspiration. Oedema and ischemia from hypothermia put the muscles in stiffness and are at risk for rhabdomyolysis. Also, hypothermia can reduce cognitive function and impair neuron conduction which can lead to death. $2,4,5,7$

Treatment of hypothermia is based on preventing further heat loss and rewarming the hypothermic victim. Handling hypothermia based on severity, mild to moderate hypothermia reduces heat loss with an additional layer of dry clothes and increases physical activity slowly in a protected environment, intake of warm fluids and sugar helps provide calories plus a source of heat, providing blankets, bodyto-body contact. which is normothermic. Severe hypothermia should be protected from any humidity in the environment, use multiple sleeping bags; blankets and clothing to keep a minimum distance of $10 \mathrm{~cm}$ between the victim and the floor. Active external heating using a hot water bottle, warm stone or warm compress towel is placed on the surface of the body that is the main artery, on the neck for the carotid, in the axilla for the brachial, in the groin for the femoral, on the palms for the arch of the artery. Severe hypothermia causes gastroparesis but the stomach can absorb water and sugar, give warm sugar water every 15 minutes. , $^{2,4}$

Hypothermia occurs because a person is in cold weather, exposed to cold winds at high altitudes, immersed in cold water, and prolonged exposure to cold.1,2,7 Hypothermia is more common in climbers, climbers admit that hypothermia is a risk they will experience when exploring the highlands with cold temperatures and strong winds, as well as when using wet wear. $^{8-10}$ Factors that aggravate the occurrence of hypothermia in climbers besides using wet clothes are fatigue or the climber's stamina. ${ }^{11-13}$

A climber in Semarang who joined the Unissula nature-loving student community (mapala) died on the mountain due to fatigue and hypothermia while participating in a one-week education and SAR training activity with 25 other students. ${ }^{14}$ Besides, students of SMKN 10 Semarang died while climbing Mount Merbabu due to hypothermia. ${ }^{15}$ Coldrelated injuries can be prevented by proper education, preparation and response to changes in ambient temperature. ${ }^{7}$ Mountain climber first aid education should be improved, education should take into account the special demands of a mountain emergency. ${ }^{16,17}$

Knowledge and attitudes are important to be maintained and improved in providing intervention in cases of hypothermia. ${ }^{18}$ The knowledge and practice of mothers and professional nurses regarding hypothermia are grossly inadequate in various evaluations. ${ }^{19}$ Based on this description, research needs to find out more about "The Relationship of Knowledge about Hypothermia to Hypothermia Management Practices in Nature Lovers Students (Mapala)".

\section{METHODS}

This research is a quantitative study using a correlation study method (cross-sectional). The population in this study were all Mapala UNISSULA, UNNES, and USM totalling 52 people. Determination of the sample using purposive sampling technique and analyzed with the sample correlation technique, the sample must be taken at least 30. The inclusion criteria were joining mapala, having participated in climbing, having practised handling hypothermia while climbing, and students majoring in nonhealth majors. The exclusion criteria for the 
study were being sick, members of Mapala who were no longer active, students majoring in health, members of Mapala who were not students. The research was conducted at the base camp each Mapala in May-June 2017. Collecting data using a questionnaire compiled by the researcher, the questionnaire has been carried out by expert testing on emergency nursing experts as well as validity and reliability tests. $^{20-23}$

\section{RESULTS}

Based on Table 1.1 the results of the research statistical test using the Spearman Rank correlation test, the correlation coefficient value is -0.064 with a $\rho$ value of $0.738(\rho \geq 0.05)$, meaning that Ho is accepted so that it is stated that there is no relationship between knowledge about hypothermia and the practice of handling hypothermia. in Nature Lovers Students (Mapala). It is known that most of the respondents practised handling hypothermia in a good category as many as 16 people (53.3\%), and 14 people $(46.7 \%)$ had bad practices. There are still practices that are in the bad category of $46.7 \%$ because $40 \%$ of respondents have not received PPGD (Emergency First Aid) education while $60 \%$ have the possibility of getting PPGD education for a long time. Apart from PPGD education, what affects bad practice is the experience of climbing the respondent at least 1 time, 4 people and only 1 person at most 27 times.

Table 1.1 Correlation of knowledge about hypothermia with hypothermia management practices at Mapala UNISSULA, UNNES, and USM, May - June 2017

\begin{tabular}{lcc}
\hline \multicolumn{1}{c}{ Variable } & R & P \\
\hline $\begin{array}{l}\text { Correlation of knowledge with } \\
\text { hypothermic treatment } \\
\text { practices }\end{array}$ & $-0,064$ & 0,738 \\
\hline
\end{tabular}

\section{DISCUSSION}

Factors that significantly affect knowledge are education, mass media or information, socio-culture and economy, environment, experience, and age. The results showed that most of the respondents' knowledge was categorized sufficient, namely as much as $56.7 \%$, the good category was $40 \%$ and the poor category was $3.3 \%$. Respondents who have not received PPGD education are as much as $40 \%$ while those who have already been $60 \%$. Experience is used as a source of knowledge by repeating the knowledge obtained to solve a problem encountered in the past and as you get older, your perceptive power will develop as well as one's mindset so that the knowledge gained is getting better. ${ }^{24-29}$

The youngest respondents were 16 years old and the oldest was 23 years old with an average age of 20 years. The respondent has experienced climbing at least once, the value of his knowledge is sufficient and the practice is good. While the experience of climbing is at most 27 times, the value of knowledge is good and the practice is not good. Knowledge is sufficient but good practice and good knowledge but bad practice are probably influenced by the number of times the respondent performs treatment practices on hypothermic victims. ${ }^{24-27}$

This research is supported by the fact that there is no relationship between maternal knowledge, mother's education and husband's support with the practice of exclusive breastfeeding. ${ }^{30}$ Mothers who provide exclusive breastfeeding to their children have high knowledge, in addition to the experiences of mothers and information received by mothers from Health workers and the work environment motivate mothers to exclusively breastfeed. ${ }^{31}$ Mothers have satisfactory knowledge of hypothermia, practical applications of mothers who have very poor knowledge. ${ }^{25}$

\section{CONCLUSION}

Hypothermia management practices in Mapala UNISSULA, UNNES, and USM were in a good category. There is no correlation 
between knowledge of hypothermia and the practice of handling hypothermia among Nature Lovers Students (Mapala).

\section{ACKNOWLEDGMENTS}

The author would like to thank the Jati Kudus Public Health Center for permitting us to conduct research. Besides, the authors also wish to thank all respondents for their participation in this study.

\section{CONFLICTS OF INTEREST}

Neither of the authors has any conflicts of interest that would bias the findings presented here.

\section{REFERENCES}

1. Angelova RA. Working in Cold Environment: Clothing and Thermophysiological Comfort. In: Occupational Health. InTech, 2017. Epub ahead of print February 2017. DOI: 10.5772/65687.

2. Nagpal BM, Sharma R. Cold injuries: The chill within. Med J Armed Forces India 2004; 60: 165171.

3. Setiati S. Buku Ajar Ilmu Penyakit Dalam Edisi IV. Jilid I. Jakarta: Interna Publishing, 2014.

4. Gelb D. Hypothermia. In: Encyclopedia of the Neurological Sciences. Elsevier Inc., 2014, pp. 657-658.

5. Biem J, Koehncke N, Classen D, et al. Out of the cold: Management of hypothermia and frostbite. CMAJ 2003; 168: 305-311.

6. Silverthorn DU. Fisiologi manusia: sebuah pendekatan terintegrasi. Edisi 6. Jakarta: EGC, 2014.

7. Fudge JR, Bennett BL, Simanis JP, et al. Medical Evaluation for Exposure Extremes: Cold. Wilderness Environ Med 2015; 26: 63-68.

8. Moore GWK, Semple JL. A tale of two climbers: Hypothermia, death, and survival on mount everest. High Alt Med Biol 2012; 13: 51-56.

9. Alfiqri FR, Prakoso H. Studi mengenai pemaknaan mendaki gunung pada pendaki seven summits expedition mahitala Universitas Katolik Parahyangan Bandung. Pros Psikol 2015; 0: 16-19.

10. Sastha HB. Mountain Ccimbing for everybody: panduan mendaki gunung. Jakarta: Hikmah, 2007.
11. Firth PG, Zheng H, Windsor JS, et al. Mortality on Mount Everest, 1921-2006: descriptive study. BMJ; 337.

12. Burtscher M. Effect of experience and commercialisation on survival in Himalayan mountaineering: retrospective cohort study. BMJ 2012; e4846.

13. Wijaya $\mathrm{H}$, Christian. Rekam jejak pendakian ke 44 gunung di Nusantara. Yogyakarta: ANDI, 2011.

14. Setyawan EH. Mahasiswi Semarang Tewas di Gunung Merbabu - News Liputan6.com. 9 Februari 2014.

15. Setiawan E. Oky Sempat Ragu Mendaki Gunung Merbabu. 9 Februari 2016.

16. Kuepper T, Wermelskirchen D, Beeker T, et al. First aid knowledge of alpine mountaineers. Resuscitation 2003; 58: 159-169.

17. Brustia R, Enrione G, Catuzzo B, et al. Results of a Prospective Observational Study on Mountaineering Emergencies in Western Alps: Mind Your Head. High Alt Med Biol 2016; 17 : 116-121.

18. Purwati T. Pengetahuan dan sikap perawat tentang hipotermi dengan intervensi keperawatan bayi berat lahir rendah (Nurse's Knowledge and Attitude in Hypothermic High Risk Infants). June 2012. Epub ahead of print June 2012. DOI: 10.5281/J NERS COMMUNITY.V3I1.3.

19. Gupta J. Knowledge, attitude and practices to hypothermia amongst nursing professionals and mothers of neonates - Asian Student Medical Journal. Asian Student Med J.

20. Effendi S, Tukiran. Metode penelitian survei. Jakarta: LP3ES, 2012.

21. Nursalam. Metodologi Penelitian Ilmu Keperawatan: Pendekatan Praktis. 4th ed. Jakarta: Salemba Medika, 2016.

22. Nasir A, Muhith A, Ideputri ME. Buku ajar metodologi penelitian kesehatan: konsep pembuatan karya tulis dan thesis untuk mahasiswa kesehatan. Yogyakarta: Nuha Medika, 2011.

23. Notoatmodjo S. Metodologi penelitian kesehatan. Jakarta: Rineka Cipta, 2012.

24. CHAN MF. Factors Affecting Knowledge, Attitudes, and Skills Levels for Nursing Staff Toward the Clinical Management System in Hong Kong. CIN Comput Informatics, Nurs 2009; 27: 57-65.

25. Madhavi P, Wickremasinghe R, Jayasooriya KBN, et al. (PDF) Title: Mothers' knowledge and practices on thermoregulation of neonates in 
Sri Lanka. Eur Int J Appl Sci Technol.

26. Maniraju, Chandra Shekar M, Williams S. A Study to Assess the Knowledge and practice of staff Nurses Regarding Thermoregulation of Neonates selected Hospital at Mysuru. Asian J Nurs Educ Res 2018; 8: 94.

27. Awadh A, Hassali M, Al-lela O, et al. Factors Affecting Parents' Knowledge And Practice About Childhood Immunization: Experience From Malaysia. Value Heal 2015; 18: A104A105.

28. Notoatmodjo S. Promosi kesehatan dan ilmu perilaku. Jakarta: Rineka Cipta, 2014.

29. Notoatmodjo S. Ilmu perilaku kesehatan.
Jakarta: Rineka Cipta, 2014.

30. Sartono A\&, Utaminingrum H. Hubungan Pengetahuan Ibu, Pendidikan Ibu Dan Dukungan Suami dengan Praktek Pemberian ASI Eksklusif di Kelurahan Muktiharjo Kidul Kecamatan Telogosari Kota Semarang. J Gizi Univ Muhamadiyah Semarang 2012; 1: 1-9.

31. Andayani, R., Setyowati, H., \& Mardiyaningsih E. Hubungan pengetahuan Ibu tentang ASI eksklusif dengan praktik pemberian ASI eksklusif pada Ibu bekerja di Kelurahan Ngempon Kecamatan Bergas Kabupaten Semarang. 